\title{
LA HISTORIOGRAFÍA ECLESIÁSTICA ESPAÑOLA CONTEMPORÁNEA. BALANCE PROVISIONAL A FINALES DE SIGLO (1976-1999)
}

\author{
POR \\ José Manuel Cuenca Toribio \\ Universidad de Córdoba
}

\section{ResumeN}

En este artículo se hace recopilación de los tíltimos veinticinco años de producción historiografica sobre la historia de la iglesia en España, analizando las nuevas tendencias y los autores más significativos de la amplia lista de publicaciones aparecidas recientemente.

\begin{abstract}
In this paper the autor makes a summary of the historiographical researchs of the last twenty-five years of Hispanic Church's history, analyzing the new ways and the most prominents autors of the wide list of publications recently publisched.
\end{abstract}

Como acaso algún lector recuerde, hace veinticinco años emprendimos un balance de la historiografía eclesiástica de la postguerra española, penetrados, como ahora, de la más firme conciencia de falibilidad y erroneidad e impulsados tan sólo por la solicitud hacia la vertiente de nuestro trabajo más intensamente cultivada; y bien percatados, por supuesto, de las espinas y quebrantos que suelen acompañar en nuestro país a toda tarea crítica por modesta y bienintencionada que sea. Pero, pese a todo, aproado ya el fin de siglo, parece oportuno acometer una empresa similar, referida, como la primera aventura, al 
marco de la contemporaneidad, con alguna que otra incursión por los tiempos de la España moderna 1 .

Con mala técnica pedagógica y narrativa, diremos en el umbral mismo de este artículo que el juicio que, al más benévolo opinante, merecerá el trabajo desplegado por los cultivadores de dicha parcela, no será sin duda optimista. Con justicia e incluso gratitud hacia él, con alabanza al entusiasmo de muchos jóvenes investigadores afanados por dar consistencia y fecundidad a este campo del quehacer intelectual, la evidencia se impone; y ella no es otra que la debilidad y el atraso que, pese a todo, aún imperan en el terreno que nos ocupa. Ni metodologica ni informativamente, el estadio alcanzado cabe compararlo con el conquistado por otras ramas de la historiografía nacional a lo largo del último tercio del siglo, en el que, con la modestia inherente a un país de estatuto científico precario como el español, varias ramas de la disciplina de Clío han logrado un perfil equiparable al de las naciones culturalmente más evolucionadas.

Sin demasiadas aficiones detectivescas y aún menos fiscalizadoras, no indagaremos las causas de las deficiencias y posibles fallos o errores que han conducido a tal situación, pesarosa pero también irrefragable. Las de más fácil recurso y apelación -las económicas- no pueden aducirse con mucho fundamento. Algunas de las instituciones con más destacado protagonismo en las décadas finiseculares -las entidades crediticias no eclusivamente lucrativas han manifestado, por sus orígenes y legislación, una amplia receptividad hacia las obras de índole eclesiástica y religiosa; de igual modo, aunque es cierto que, tras el concilio Vaticano II, las editoriales comerciales amenguaron un tanto su atención por dicha temática, no lo hicieron hasta tal extremo de mostrarse insensibles a libros de positivo interés o ancha audiencia; $y$, finalmente, no cabe olvidar que algunas diócesis de especial bonanza material o de antenas culturales muy alertadas poseen desde hace tiempo centros y organismos dedicados a la promoción y desarrollo de su legado históricomonumental. Por lo que hace al Estado, tampoco sus universidades e institutos de investigacion han dejado

1 Publicado en 1975 en el Bol de la Real Academia de ta Historia, «Materiales para el estudio de la Iglesia jerárquica espaniola contemporánea. Episcopologios, biografías, obras de carácter general», lo recogimos posteriormente en el libro Estudios sobre el catolicismo espaniol contemporáneo. Cóndoba, 1990, vol. I. Desde entonces, otros estudiosos han acometido una empresa de semejante indole y parecidos objetivos que, naturalmente, han de reseffarse: F. GARCIA CORTAZAR, «La nueva historia de la Iglesia contemporánea en Españan. Apud Historiografía española contemporanea. $\boldsymbol{X}$ Coloquio del Centro de Investigaciones Hispánicas de la Universidad de Pau. Balance y resumen. Madrid, 1980, pp. 207-231; J. ANDRES GALLEGO, «La historia religiosa en España», Anuario de Historia Eclesiástica de Espafia, IV (1995), pp. 259-269, y E. BERZAL DE LA ROSA, «La Historia de la Iglesia espafiola contemporánea. Evolución historiográficas, Anthologica Annua, 44 (1997) , pp. 633-674.

Hispania, del Mediterráneo al Atlantico

Hispania Sacra 51 (1999) 
de dedicar medios a los trabajos de la especie mencionada; objeto igualmente de particular cuidado en los establecimientos de rango superior sostenidos por la Iglesia Católica en España, a la manera, entre otros, del «Instituto de Historia de la Iglesia» en la Universidad, dirigida por el Opus Dei, de Navarra o los de las Universidades Pontificias de Comillas y Salamanca o, en Roma, el «Instituto Español de Historia Eclesiástica».

Sin muchos mecenas ni esponsores - ¿qué rama de las Humanidades los posee en nuestro país?-, no puede, pues, responsabilizarse de la escasa cosecha entrojada durante cerca de treinta años por la historiografía eclesiástica del periodo contemporáneo al desvío o desatención de la sociedad y los poderes públicos. Los motivos principales de estos deficientes resultados habrá, por consiguiente, que buscarlos en planos como la estrategia investigadora o el arcaísmo de las técnicas aplicadas. De todo ello hay, en efecto. Por el lazareto al que, injusta y sectariamente, se ha visto sometida dicha materia en los ambientes de vanguardia universitarios durante los decenios decisivos en que las disciplinas sociales experimentaban una saludable renovación en metas y utillaje, la coordinación de esfuerzos y, no pocas veces, la mínima cooperación faltaron entre sus focos de investigación y los estudiosos mismos, condenados a un lamentable ostracismo, muy connatural, no obstante, a buena parte de los de condición clerical, sobre todo, cuando formaban parte de las congregaciones y órdenes regulares. El fruto de ello, según es fácil imaginar, fue desatrado para formar una auténtica comunidad científica, con planes medianamente rentables desde el punto de vista investigador y editorial.

El panorama reinante en los años sesenta y setenta no cambiaría en lo sustancial en las postrimerías de la actual centuria, ahondándose con ello la distancia entre la historiografía religiosa y la de otras esferas en cuanto a rigor y sistemática planificadora. Un ejemplo lo patentizaría con gruesos caracteres. Bien que, conforme ya hemos expuesto con cierta latitud en otro lugar, las extensas historias generales de la nación española dirigidas sucesivamente por el tándem Menéndez Pidal-Jover Zamora (quien remplazó,según se conoce, al primero, una vez fallecido D.Ramón en 1968), la triada de L. Suárez, J. L. Comellas y J. Andrés Gallego así como las de menor amplitud y ambición pilotadas por M. Tuñon o M. Artola, entre otros, no se hayan caracterizado de ordinario, desgraciadamente, por su acribia y unidad de objetivos y desarrollos, las eclesiásticas han ofrecido una imagen todavía más defectuosa ${ }^{2}$. Así sucedió

2 Vid J. M. CUENCA TORIBIO, «De historia e historiadores espanfoles contemporáneos». Historia y Vida, 240 (1988), pp. 111-126. Por su parte, un especialista acabado de citar afima: «[...] La consecuencia historiográfica está bien clara: el pudor de los historiadores laicos católicos- ante la historia de la Iglesia, a la hora de hacerla o de trazarla. Todos somos capaces de hablar de historia religiosa, todos de becho hablamos; todos, además, tenemos que hablar, porque no cabe negar que empapa nuestra 
con la que, por la nombradía de sus pilotos, el prestigio de su marbete editorial y el esfuerzo ilusionado de sus colaboradores (entre los que figuró, postremus inter pares, el autor de estas líneas), con más expectación se recibio su botadura: Historia de la Iglesia en España. (Madrid, BAC, 1979, 5 vols.). Con aportaciones de primer orden por la enjundia e impecable método, su horizonte global no ha podido ser, por lo común, más fragmentario, defectuoso y anárquico en cuanto a documentación, estilo y técnica. En líneas generales, el nivel de los conocimientos estaba desfasado y no otra cosa ocurriría con su talante, a menudo anclado en la hagiografía más declarada. Las síntesis más divulgadas y con mayor reclamo publicitario y editorial del trabajo de los historiadores de la Iglesia española moderna y contemporánea ofrecieron de esta forma y acaso, en buena parte, como producto logico e inevitable de la dispersión y pobreza de su dimensión monográfica, una muestra poco atractiva y muy censurable de la desconexión de sus núcleos investigadores, cuyo esfuerzo no lograba sobreponerse al estadio meramente erudito y apologético en que se desenvolvía simultáneamente el mayor número de obras consagradas al análisis de nuestro pasado religioso inmediato.

Otra cara del mismo fenómeno se observa en la circunstancia de que ningún libro de la materia abordada en las presentes páginas figuraría en el hit parade de la bibliografía española de finales del novecientos. La que estuvo quizá más cerca de ello-Arxiu Vidal $i$ Barraquer. Església $i$ Estat durant la Segona República Espanyola. Textos en la llengua original, Edició a cura de M. Batllori y V. M. Arbeloa (Monestir de Montserrat 1971-94)- no se presentó, en realidad, como un estudio de la religiosidad propiamente dicha, al tiempo que en sus páginas el trabajo de creación se reducía al de unos documentalistas muy avisados y competentes. Posiblemente, el que los libros de uno de los más descollantes cultivadores de la historiografía religiosa contemporánea, Manuel Revuelta González -La exclaustración (1833-1840) (Madrid, 1976, 503 pp.) y La Compañía de Jesús en la España contemporánea 1868-1883 y 1884-1906, (Madrid, 1984 y 1991, 1. 227 pp. y II, 371 pp., respectivamente

historia. Pero una cosa es narrar y analizar la II República y destacar en el análisis lo propio de la Iglesia como algo insoslayable, incluso principal, y otra rehacer la historia de la Iglesia entre 1931 y 1936, por ejemplo.

Digo que es otra cosa, no ya en el plano metódico, sino en el de los ánimos de los historiadores. Los más preferimos hacer aquello y no esto. Preferimos abordar el asunto religioso solo como una parte de otro de más envergadura. Eso es sin duda útil para no caer en un trascendentalismo regresivo. (Tampoco el integrismo español deja de ser un remedo menor del extranjero). Pero no nos permite entrar de lleno en la problemática religiosa en sí.

Consecuencia: ausencia de instituciones de historia de la Iglesia, de historia religiosa, escasez de especialistas seglares o laicos: predominio de los historiadores de condición y to que al cabo importamentalidad eclesiástica, tan respetable, es cierto como inclinada a un tipo de problemas y no a otros:» J. ANDRES-GALLEGO, «La historia religiosa...», p. 267.

Hispania, del Mediterráneo al Atlántico

Hispania Sacra 51 (1999) 
encetado ya el tercer y último tomo de esa excelente historia, según amable información del catedrático de Comillas al autor de estas líneas)- no rompieran las barreras antedichas debióse a otros factores de los expuestos más arriba; aunque tampoco quepa descartar la carencia de tejido científico y densidad intelectual a la que nos referíamos ha un instante como otro de los elementos que intervinieron en que la irradiación de obras tan meritorias y bien escritas no obtuviesen el eco exigido por su calidad.

A su vez, y en conjunto, el tono y contenido de las revistas exclusiva o primordialmente destinadas a la publicación de estudios históricos concernientes al pasado religioso contemporáneo no han variado respecto a los que las distinguiera en los días de la postguerra y del régimen de Franco. En ninguna se ha producido un cambio de estructuras y fines; y en muy pocas, temática y utillaje instrumental se han acomodado al clima general. Desdichadamente, las nacidas en el periodo aquí reseñado no han ampliado hasta el momento el paralaje temático o metodológico. La rutina y la insipidez continúan, consiguientemente, enseñoreadas de un vehículo tan fundamental para la actualización de cualquier disciplina como es el de las revistas y publicaciones periódicas.

Pero si en la dimensión más creativa y difícil del esfuerzo historiográfico no se pueden constatar progresos de cierta entidad en la especialidad objeto de estas líneas, podía esperarse encontrarlos en campos de más expedito acceso. Así, por ejemplo, en el desarrollo de la historia institucional de la Iglesia, tal y como ha ocurrido en Francia y en algunos países de la francofonía, al modo de Canadá, con el estudio de las diócesis. Pocas instancias eclesiásticas o civiles (ya que también a las esferas de éstas afecta, y mucho...) han sentido en nuestro país la necesidad de promocionar una reconstrucción integral del pasado de las sedes episcopales. Contamos con un número muy reducido de ellas, desiguales e insatisfactorias por lo general, pero que, no obstante, hacen anhelar que tal iniciativa se secunde por los restantes obispados y arzobispados, pues su existencia, aun defectuosa, será siempre mejor que el vacío ${ }^{3}$. La obra póstuma en puridad, recopilación de trabajos anteriores- de Demetrio Mansilla Reoyo, Geografía eclesiástica de España. Estudio histório-geográfico de las diócesis

3 V. gr. Historia de la Iglesia en Valencia. Valencia, 1986, 2 vols.( Hay igualmente una edición reducida de dicha obra: Breve Historia de la Iglesia en Valencia, Valencia, 1990, 233 pp); Historia de la diocesis de Valladolid. Valladolid, 1996, 627 pp. La primera tiene como autor solitario a un reconocido especialista, V. CARCEL ORTI, y en la redacción de la segunda han intervenido historiadores tan reputados como T. EGIDO, M. BARRIO GoZALO, J. R. DIEZ ESPINOSA, E. MAZA ZORRILLA o J. M. PALOMAREs IBAN̂EZ. En el otoño de 1998, la dirección de la cada vez más sesteante y rutinaria BAC comunicaba la feliz noticia de que, bajo la guía del canónigo ovetense J. L. GONZALEZ NovaliN, acreditado modernista, estaba en fárfara el estudio de todo el pasado de las diocesis hispanas, al que deseamos su pronta realización. 
(Roma, 1994, vol. I, 396 pp.; vol II, 555 pp.) asienta firmemente las bases de esa futura tarea, no obstante sus comprensibles limitaciones y deficiencias, registradas elegantemente por su prologuista, Mons. Justo Fernández Alonso.

Otro tanto cabe afirmar de los episcopologios, bien que aquí el panorama es más reconfortante, al menos en cantidad, ya que no a menudo en la excelencia. Su puesta a punto en algunos casos, su elaboración casi ex nihilo en otros, no siempre ha entrañado el salto adelante que era lícito desear; pero al menos permite disponer ya de un material relativamente idoneo para afrontar con garantía el reto de estudiar con la debida contextualización y hondura un costado básico de la historia religiosa y civil española. Ningún testimonio puede acudir en este extremo de manera más plausible a los puntos de la pluma que el coronado por el infatigable canónigo iruñés José Goñi y Gaztambide, pionero en buena medida de nuestra historia eclesiástica medieval: Historia de los obispos de Pamplona (Pamplona, 1981..., X vols. aparecidos), abriéndose en los comedios del tomo VIII (1989) la edad contemporánea y continuando en el IX (Pamplona, 1991, 740 pp.) y X (Pamplona, 1991, 597 pp.) las biografías de los prelados decimonónicos. A partir de su benemérito esfuerzo, el futuro historiador dispondrá de una guía sólida -por su documentación más que por su análisis, inmatizado y hasta eutrapélico en no pocos tramos para reconrer el itinerario de una de las diócesis de mayor influencia en los destinos del catolicismo español ${ }^{4}$.

Muy expresiva de la deprimida atmósfera que rodea la historiografía contemporánea eclesiástica es la lentitud del proceso renovador y la dificultad de poner en marcha empresas de algún calado al nivel de los tiempos y de radio estatal o, cuando menos, autonómico. Tal vez por ello, su inexistencia o parquedad. Después de la rotunda frustración que acompañó a la ilusionada tarea interdisciplinar de una radiografía del anticlericalismo, la maldición semeja persistir sobre esta suerte de iniciativas de tan evidente interés como ostensible urgencia si se desea nuclear la investigación de nuestro pasado religioso sobre extremos fundamentales de su dinámica. En un plano menos ambicioso, proyectos encaminados a la actualización de ciertos episodios y capítulos esenciales de la historiografía eclesiástica contemporánea de raigambre católica, tales como, sin ridículos propósitos de exhaustividad, el regeneracionismo de

4 Aunque no hacemos nuestra la integridad de su juicio, reproducimos el siguiente de una historiadora de la cultura espaniola a causa de su expresividad respecto a varias de las ideas expuestas en el texto y, de modo particular, acerca de nuestra última reflexión: «En la Historia de la Iglesia Catolica de la B.A.C., Madrid, 1963, la sección dedicada al siglo XIX, «La Iglesia y el Estado en España y Portugals, tomo V, pp. 525-591, a cargo de R. García Villoslada, S. J., es predominantemente tendenciosa en su trato de la Restauración. El autor deja de lado su objetividad científica para descargarse contra los intelectuales del 98, contra Giner de los Ríos, a quien lama el «santón laico», cuya misión era laicizar a España», p. 563. M. CAMPOMAR FORNIELES, «Cuarenta años de menendezpelayismo», Espacio, Tiempo y Forma. Historia Contemporánea, 7 (1994), p. 680.

Hispania, del Mediterráneo al Atlántico

Hispania Sacra S1 (1999) 
corte confesional,la prensa religiosa,la presencia cultural de los católicos,el fermento religioso tradicional en los nacionalismos más pujantes o el ingrediente católico en el nacionalismo español,naufragaron en la impotencia, pese a logros y aciertos en algún caso muy valiosos, debido a la ausencia de directrices bien apuntadas o a la infirmidad de los materiales aportados por plumas intonsas o agraces. Los huecos deben rellenarse con piezas extraídas de canteras bien abastadas, ya que, de lo contrario, se estará condenado a la improvisación permanente.

El fruto, serondo en su conjunto, recogido por el magno esfuerzo -rectorado admirablemente por Ferrer Benimelli- para asentar sobre firmes pilares el análisis de otro tema recurrente y capital de la contemporaneidad española como es el de la Masonería demuestra, sin embargo, que no hay ningún torcedor invencible que aquí, como en cualquier otro terreno de la actividad investigadora, no pueda vencerse con trabajo meditado y unión de energías. Reiterativa en ocasiones, prematura o frágil a las veces, la contribución de muy variados y numerosos estudiosos ha respondido a las expectativas despertadas (-en un clima proclive a la polémica e invadido más de lo deseable por la descalificación y el anatema-) merced a una planificación notable y a una coordinación sobresaliente.

Poco fructifferos en el surco colectivo, los afanes investigadores se han refugiado por lo común en un territorio más propicio, en el tan hispano del robinsonismo. En ciertas parcelas y en más de una coyuntura, tal sistema de trabajo puede dar resultados felices. Un tratado o una visión de conjunto acometidos desde una óptica individual o con el concurso de dos o tres autores ofrece teóricamente indudables ventajas en ocasiones. No obstante, las obras españolas colocadas en tales coordenadas se han descubierto por debajo de la previsible notabilidad. Nomina ominosa sunt, aquí, como en todo el universo del crítico, que, junto con la prudencia, ha de extremar su conciencia de falibilidad y errancia. La labor, encomiable por más de una razón, de Gonzalo Redondo al trazar, con paso detenido, el itinerario más reciente de la Iglesia hispana -Historia de la Iglesia en España. 1931-1939 (Madrid, 1993, 2 vols., en curso de publicación)- no se ha visto recompensada a causa de lagunas de amplio radio en el aparato documental y bibliográfico y, singularmente, por los acentuados prejuicios -a las veces, maniqueístas- desde los que se enfoca tal andadura. Idéntica esperanza podía albergarse al comenzar la lectura de Quintón Aldea y Eduardo Cárdenas, Manual de Historia de la Iglesia. Tomo X. La Iglesia del siglo XX en España, Portugal y América Latina, (Barcelona, 1987), acrecentada por el encuadramiento ibérico de la trayectoria de la religión cristíana. La participación española a cargo de un muy sobresaliente modernista y un no menos afamado politólogo, Antonio Marquina, no satisface siempre, 
empero, las exigencias que tanto la casa editora como el nombre de los autores y la responsabilidad de la tarea requerían.

También aquí, pese a la renitencia a admitir poderes ocultos en el despliegue de nuestra bistoriografía eclesiástica, se está tentado de atribuir a algún sortilegio o maldición desconocida hechos como éste: más de un siglo después de la aparición de Historia Eclesiástica de España, 6 vols. (Madrid, 1873-75), de Vicente de la Fuente, ningún autor ha llevado a cabo una síntesis aceptable por su planteamiento y desarrollo del catolicismo español. Su realidad se alza como aporía insalvable frente a todo conformismo o enmascaramiento de un fenómeno que es por sí mismo una denuncia de muchos vicios y deformidades de nuestra vida científica e intelectual. Ni siquiera en esta vertiente el acendrado individualismo hispano se ha probado eficaz.

Sí lo ha sido, por el contrario, en tareas de menor porte y trascendencia. La edición de la documentación evacuada por los diversos nuncios decimonónicos a cargo de Mons. Cárcel Orti ha sido indudablemente una de ellas -comenzó con Correspondencia diplomática del Nuncio Tiberi (1827-1834) (Pamplona, $1976,873 \mathrm{pp}$.) y concluyó, confíamos que provisionalmente, con la de su sucesor -Correspondencia diplomática del nuncio Amat (1833-1840) (ibid, 1982, $374 \mathrm{pp}$.)-. Aunque no toda la historia de la Iglesia española contemporánea se encierra en los archivos vaticanos, es claro que el magno esfuerzo que ha supuesto la meticulosa exhumación resulta acreedor al aplauso más encendido. La perentoriedad de disponer de esos fondos del Archivo Secreto Vaticano ha sido muy seguramente la principal causa de que tales publicaciones no sean auténticas ediciones críticas, para cuya consecusión se hubiera requerido el concurso de varios especialistas o un tempo más demorado y de menor ritmo del que, por los motivos justificados ya indicados, se le ha impresos. Por el sobresaliente interés y riqueza de la información no vacilamos en mencionar

3 «En la presente edición he seguido el método ya iniciado en el volumen dedicado a Tíberi, es decir, transcripción íntegra de todos los despachos dirigidos por el nuncio a la secretaría de Estado y de las respuestas que ésta les remitión. Correspondencia diplomática del Nuncio Amat (1833-1840). Pamplona, 1982, XII. Un decenio más tarde de escrito el anterior párrafo, su autor daba noticia del método seguido en su trabajo y en el archivo de la Nunciatura de Madrid: «Tras haber consultado varias cajas correspondientes a los pontificados de Gregorio XVI $(1831$-1846) y de Pio IX (18461878), el fallecido padre Burkhart Schneider, entonces vicerrector de la Gregoriana y profesor de Historia de la Iglesia contemporánea, me animó para emprendiera de forma sistemática la edición de dichos índices ofreciéndome con generosidad la revista Archivium Historiae Pontificiae, de la que él era director, para dar a conocer mi tarea. El plan era muy ambicioso porque, además de dar a conocer el contenido de cada una de las cajas, divididas por nunciaturas, mi proyecto consistía en catalogar los despachos que los nuncios enviaron a la Secretaría de Estado y las respuestas de esta, como fase previa para la edición de toda la correspondencia diplomática de los nuncios del siglo XIX». «El archivo de la Nunciatura de Madrid. Una fuente para la historia de España y de Hispanoaméricas, Hispania, 181 (1992), p. 592. 
específicamente dentro del valioso elenco bibliográfico citado el volumen León XIII y los católicos españoles. Informes vaticanos sobre la Iglesia en España. (Pamplona, 1988). De sus 954 pp., 198 componen la introducción, útil y precisa, pero inclinada a la erudición más que al análisis y algo también reiterativa. Importante y acreedora a loanzas lo es igualmente la edición de las Actas de las Conferencias de Metropolitanos Españoles (1921-1965). (Madrid, 1994,847 pp.). De igual modo, la entrega a las prensas de múltiples relaciones de visitas ad limina de un alto número de las diócesis de la Península y de los Archipiélagos exige el rendido agradecimiento de los especialistas, más distanciados, sin embargo, de sus libros de investigación, lastrados por la fragilidad del aparato teórico y una apologética de pasados tiempos y un tanto toscos, a las veces, metodológica y estilísticamente, a la manera, entre otros, de Política eclesial de los gobiernos liberales españoles. 1830-1840. (Pamplona, 1975, 530 pp.), Iglesia y revolución en España (1868-1874) (Pamplona, 1979, $682 \mathrm{pp}$.) -que nos cupo la distinción de dirigir durante nuestra inolvidable estadía valenciana en su primitiva versión como tesis de doctorado-, La persecución religiosa en España durante la segunda República (1931-1939) (Madrid, 1990, 408 pp.) o Mártires españoles del siglo XX. (Madrid, 1995, 659 pp.). En los últimos, a la fecha, libros de tan laborioso monseñor, Pasión por el sacerdocio. Biografia del siervo de Dios José María García Lahiguera (Madrid, 1996, 460 pp.) y Pablo VI y España. Fidelidad, renovación y crisis (1963-1978) (Madrid, $1997,1049 \mathrm{pp}$.), el enfoque gana en paralaje, pero sin llegar a verse acompañado tan positivo cambio por otros en los restantes campos mencionados.

Dichas carencias son menos visibles, como es obvio, en aquella vertiente de la vasta y benemérita producción del autor consagrada nuclearmente a la exhumación y glosa de un sinnúmero de capítulos de las relaciones Iglesia y Estado en la historia española contemporánea, en especial, los atingentes al nombramiento de obispos. De un acervo bibliográfico, como decimos, muy amplio y elogiable nos atreveríamos a recordar los siguientes de los que hemos hecho acezante lectura: «El Archivo de la S. C. de Asuntos Eclesiásticos Extraordinarios. I. Fuentes para la Historia de España desde sus orígenes hasta la muerte de Pío LX (1878)», Italica. Cuadernos de Trabajos de la Escuela Española de Historia y Arqueología en Roma, 15 (1981), 247-320 pp., artículo que encuentra su continuación en este otro, «La Congregación de Asuntos Eclesiásticos Extraordinarios y España (1814-1913)», Archivum Historiae Pontificiae, 31 (1993) y, en parte, en «Una fuente para la Historia de España y de Hispanoamérica: el Archivo de la Nunciatura de Madrid», Hispania, 181 (1992), pp. 585-608, republicado con el título «El Archivo de la Nunciatura de Madrid. 25 años de investigaciones sobre la Iglesia en España», Hispania Sacra, 91 (1993) pp. 367-384, con la supresión del último parágrafo de la nota 9 y de todo el apartado dedicado al mundo hispanoamericano, añadiéndose en la 
republicación a partir de «posteriores» la siguiente línea: «así como la vida y actividad del clero y la historia interna de la Iglesia», con dos notas, 158 y 159 , en las que se da noticias de importantes trabajos encetados por el diligente autor, que tampoco figuran, lógicamente, en la publicación aparecida en Hispania; «El archivo de Pietro Gravina, nuncio en España (1803-1817), Escritos del Vedat, 9 (1979), pp. 333-320; «El archivo del nuncio en España, Giacomo Giustiniani, (1817-1827)», Ibid, 6 (1976), pp. 265-300; «Instrucciones al nuncio Barili en 1857», Revista Española de Derecho Canónico, 35 (1979), pp. 159-185; «Instrucciones a Simeoni, primer nuncio de la Restauración», Ibid (1977), pp. 143-172; «Instrucciones a Cattani, último nuncio de Pío IX en España», Ibiđ (1982), pp. 253-284; «El archivo de los nuncios de León XIII en España. I. Nunciatura de Cattani (1877-1879)». Italica. Cuadernos de trabajos de la Escuela de ..., 16 (1982), pp. 237-64; «El Archivo de los nuncios de León XIII en España. II. Nunciatura de Bianchi (1879-1883)», Ibid, 17 11984), pp. 232-262; «Los obispos españoles y la división de los católicos. La encuesta del nuncio Rampolla» y «Católicos liberales e integristas en la España del Ochocientos» Analecta Sacra Tarraconensia, 55-56 (1982-3), pp. 107-207 y 63-64 (1990), pp. 285-422; «Estado material, académico y moral de los Seminarios españoles durante el siglo XIX», Seminarios, 26 (1980), pp. 267-432; «Instrucciones del Cardenal Gasparri al Nuncio Tedeschini en 1921», Revista Española de Derecho Canónico, 131 (1991), pp. 455-482; «Instrucciones de Merry del Val a Vico en 1907 y relación final del Nuncio en 1912», Ibid, 133 (1992), pp. 567-605; «Intervención del Cardenal Merry del Val en los nombramientos de obispos españoles (1903-1914), Archivum Historiae Pontificiae, 32 (1994), pp. 253-291; «Instrucciones de la Congregación Consistorial al nuncio Ragonesi en 1913 sobre el estado de las diocesis españolas», Revista Española de Derecho Canónico; «San Pro X y la primera asamblea del episcopado español en 1907», Archivum Historiae Pontificiae, 16 (1988) pp.195373; «Nombramientos de Obispos en España durante el Pontificado de San Pío X (1903-1914)», Analecta Sacra Tarraconensia, (1995), pp. 235-423; «Los nombramientos de obispos en España durante el Pontificado de León XIII. Primera parte: 1878-1884», Ibid, (1996); «Los nombramientos de obispos en España durante el Pontificado de León XIII. Segunda Parte: 1885-1903», lbid (1997), pp. 331-504; «Benedicto XV y los obispos españoles. Los nombramientos episcopales en España desde 1914 hasta 1922», Archivum Historiae Pontificiae, 29 (1991), pp. 197-254; «Idem», 30 (1992), pp. 291-338; «Benedicto XV y el catolicismo social español», Analecta Sacra Tarraconensia, 6364 (1990), pp. 7-152; «Iglesia y Estado durante la Dictadura de Primo de Rivera (1923-1930)», Revista Española de Derecho Canónico, 45 (1988), pp. 209248; «Los nombramientos de obispos durante el régimen de Franco». Ibid, 50 (1993), pp. 553-589 (6); «El movimiento social católico en España a principios

Hispania, deI Mediterráneo al Atlántico Hispania Sacra 51 (1999) 
del siglo XX», Italica. Cuadernos de trabajos de la escuela de..., 18 (1990), pp. 257-318; «La visita apost6́lica de 1933-34 a los seminarios españoles», Anuario de Historia de la Iglesia, II, (1993), pp. 127-150. Muy atraído siempre por la temática eclesiástica de su región natal, no dudaríamos en destacar, en el aspecto ahora concernido, un artículo sobre la cuestión que desbordó con creces el marco provincial: «Nombramiento y renuncia del Arzobispo de Valencia, Fr. Bernardino Nozaleda y Villa, O. P.», Archivo Dominicano, 8 (1978), pp. 193-413 y asimismo los titulados «La Inquisición valenciana en el siglo XIX y la ejecución de Cayetano Ripoll», Boletín de la Sociedad Castellonense de Cultura, 64 (1988), pp. 415-431; «El clero valenciano en el ocaso del siglo XIX», Anales Levantinos, 6 (1980), pp. 357-846. Su último libro en colaborací́n con R. Fita Revert, Mártires Valencianos del siglo XX. (Valencia, 1998, 509 pp.) es otra fehaciente -y notable-, prueba de lo expuesto, abarcando, en realidad, su temática desde los orígenes del catolicismo levantino.

Más apegado al estudio y edición de fuentes romanas sin que por ello haya renunciado a obras de mayor empeño creativo, se recorta en el horizonte historiográfico silueteado en estas páginas el jesuita navarro F. Díaz de Cerio. En compañía, a veces, de otra notable historiadora eclesiástica, la madre $\mathbf{M}^{\mathbf{a}}$ Felipa Núñez -El bienio progresista (1854-1856) y la ruptura de relaciones de Roma con España según los documentos vaticanos (Santa Cruz de Tenerife, 1993)-, y en solitario las más, el autor de una biografía tan destacada como la que consagrara a Fray Ceferino González ha puesto a disposición de los especialistas parcelas muy extensas del deposito documental obrante en los archivos vaticanos sobre diversos aspectos de nuestro catolicismo decimonónico. Abrió la marcha de tan benemérita labor un pulcro Regesto de la correspondencia de los obispos de España en el siglo XIX con los nuncios, según el fondo de la nunciatura de Madrid en el Archivo Vaticano (1791-1903). Tres tomos aparecidos en La Ciudad del Vaticano, 1984, 690, 676 y 716 pp. respectivamente; al que siguí otra larga serie de trabajos documentalistas publicados en ocasiones en la revista Anthologica Annua, y que casi todos vieron posteriormente la luz como libros 0 , por mejor decir, según la terminología del Ins-

6 Todos estos meritorios estudios cabe calificarlos como excerpta, con muy desigual tratamiento en cuanto a extension, ya que, junto a introducciones amplias, se agrupan otras muy reducidas; e iguales diferencias pueden constatarse en su rigor historiografico, pues, a las veces, en un conjunto muy atildado se encuentran disonancias un poco estridentes (V.gr. Silvela,»liberal» y primer ministro en los inicios del «quinquenio glorioso» sagastino. «Los nombramientos de obispos en España durante el pontificado de León XIII. Segunda parte...», p. 323 El diablo de las imprentas todo lo añasca, especialemente en los autores prolíficos..Ast,por ejemplo, en el trabajo ya citado «El movimiento social católico,...el tónlo del precedente «La «visitatio Generalis» de 1555 en el Archivo de Santiago de los españoles de Roma... continúa titulando al de Monsefior Cárcel. 
tituo Español de Historia Eclesiástica de Roma, «subsidia»7: Nuevas noticias sobre el siglo XIX español en el fondo «Spogli» del Archivo Vaticano (Anthologica Annua, 33 (1987) pp. 459-611; Subsidia: Roma, 1986, 160 pp.); Noticias sobre España en el Fondo Secretaría de Estado (249 del Archivo Vaticano (lbid, 34 (1987) pp. 505-770, Subsidia: Roma, 1988, 270 pp.); «El fondo «Rescritti di facoltá» del Archivo Vaticano (1821-1908). Noticias sobre España en el siglo XIX». (Ibid, pp. 387-690, Subsidia: Roma, 1991, 310 pp.); Informes y noticias de los Nuncios en Viena, París y Lisboa sobre la España del siglo XIX (1814-1846). I: Los Nuncios en Viena (Ibid, 36 (1989), pp. 543-792 (Subsidia: Roma, 1990, 258 pp.). T. II: Los Nuncios en Lisboa (Roma, 1990, 130 pp.) .T. III: Los Nuncios en París (Roma, 1990, 390 pp.); Indice-Catálogo del Fondo de la Nunciatura de Madrid en el Archivo Vaticano (1794-1899). T. I: 1794-1840. (Roma, 1993, 566 pp.); T. II: 1847-1875. (Ibidem, 606 pp.); T. III: 1875-1899 (Ibidem, 702 pp.); esfuerzo ciclópeo que, unido al desplegado por J. de Olarra y su viuda M. L. de Larramendi y al del benemérito archivero gerundense Josep María Márquez, ha permitido reconstruir uno de los frescos más dilatados que atesora la historiografía eclesiástica moderna y contemporánea en su faceta documental. El mismo jesuita navarro dio a la luz en la desaparecida revista Scriptorium Victoriense un provechoso «Regesto de las cartas y documentos de Diego Mariano Algualcil y Rodríguez, obispo de Badajoz, Vitoria y Cartagena y se que se encuentran en el «Archivo de la Nunciatura de Madrid», 26 (1979) pp. 97-110; así como otro igualmente útil «Regesto de la correspondencia de los obispos de Pamplona con los nuncios en el siglo XIX, según el Archivo de la Nunciatura de Madrid», Príncipe de Viana, 154-55 (1979), pp. 177-202. No se desperdiciará tampoco el tiempo con la lectura de su estudio «Notas sobre el Jansenismo español en 1820-1825», Scriptorium Victoriense, 23 (1976). Desdichadamente, es menos enjundiosa la interpretación que hace de la política eclesial del trienio a través de la cata biográfica en un obispo sobre el llamamos la atención en 1965: «Para la historia del Reformismo español. G. Martínez y Riaguas, obispo de Astorga (1819-1824)», Anthologica Annua, 42 (1995), pp. 11-296 (apéndice documental -en extremo valioso- a partir de pág. 175)

Otro sacerdote español, con habitual residencia en la Ciudad Eterna, el canónigo ovetense José Luis González Novalín, ha exhumado del Archivo Secreto Vaticano con impecable técnica documentalista: Las Visitas «ad Limina» de los Obispos de Oviedo (1585-1901). Una fuente eclesiástica para la historia de Asturias (Oviedo, 1986, 344 pp.). Finalmente, en lo que toca a tal extremo, no debe olvidarse otra notable contribucion: la de R. Corts i Blay, Re-

7 «Subsidia: catálogo e inventarios de fondos de archivos y bibliotecas romanos con documentanción referente a Españan.

Hispania, del Mediterráneo al Atlántico Hispania Sacra 51 (1999) 
gests de la documentació del segle XX sobre Catalunya i la Santa Seu conservada a l'Arxiu Secret Vatica. I. Fons de la Nunciatura de Madrid (1899-1921) (Barcelona, 1992, 345 pp.). En fin, aunque de carácter misceláneo será de utilidad el libro coordinado por el benémérito canónigo archivero José María Fernández Catón Los archivos de la Iglesia en España (León, 1978, 294 pp.)

Todo lo expuesto hasta el momento no exime de una veloz recalada en el trabajo individual, de horizontes forzosamente limitados pero no angostos, llevado a buen puerto por autores de acreditada solvencia y cuya mención es muy grata a una pluma que, à rebours en su obligada función notarial, corre el peligro de adentrarse por el camino de los aristarcos. Un prolífico autor que cuenta en su haber con importantes contribuciones a la materia aquí analizada en sus variadas facetas de artículos, monografías y libros, es José Andrés Gallego, singularmente atraído por los aspectos sociales de la acción de la Iglesia y de los católicos en los avatares contemporáneos de nuestro país. Como piedra miliar de esta andadura debe recordarse la sobresaliente y provechosa obra Pensamiento y acción social de la Iglesia en España (Madrid, 1984, 427 pp.). Bien impostados documental y bibliográficamente, sus estudios manifiestan una incoercible tendencia a abrir incesablemente caminos nuevos, con hipótesis y sugerencias del mayor interés, pero brotadas con torrencial fecundidad sin la prueba de contraste exigida en más de una ocasión. Como elocuente ejemplo cabría citar su, por lo demás, notable obra ¿Fascismo o Estado católico? Ideología, religión y censura en la España de Franco. 1937-1941 (Madrid, 1997, $283 \mathrm{pp}$.). Sus responsabilidades administrativas y editoriales director desde 1986 de la revista Hispania Sacra- le han incitado, por fortuna, a promover y coordinar los estudios de base de los que todavía, según hemos reiterado ad nauseam en este y otros lugares, tan menesterosa se halla la historiografía religiosa contemporánea. La larga y fecunda experiencia del susomentado especialista en obras de colaboración facilitará sin duda tan urgente empeño - Los españoles, entre la religión y la política. El franquismo y la democracia, en compañía de Luis de Llera y A. M. Pazos; con éste último la espléndida Histoire religieuse de l'Espagne (París, 1998, 289 pp.), síntesis modélica. El propio José Andrés-Gallego y A. M. Pazos han desarrollado este último libro en los dos volúmenes titulados La iglesia en la España contemporánea, 1800-1999, (Madrid, 1999,457 y 326 pp.).

Historiador igualmente de fácil pluma y laboriosidad incansables el catedrático murciano Juan Bautista Vilar R6denas. Reclamado por muchos episodios y temas del pasado más reciente español, su dimensión eclesiástica y religiosa se ha visto muy beneficiada de su esfuerzo. Las cuestiones atañentes al mundo de la información y al protestantismo han sido las más enriquecidas por sus trabajos, sólidos y bien implementados -Un siglo de protestantismo en España. 
(Aguilas-Murcia, 1893-1979). Aportación al estudio del acatolicismo español contemporáneo (Murcia, 1979, 322 pp.) que tuvimos el privilegio de prefaciar; y la muy notable panorámica Intolerancia y libertad en la España contemporánea. Los origenes del protestantismo español actual. (Madrid, 1994, 452 pp.)

La referencia a la reforma protestante nos fuerza, algo d rebours, a una breve estación en el tema ya más arriba mencionado de la masonería, la otra bestia negra del catolicismo hispano de las dos postreras centurias. Aunque la copiosa y sistemática producción de J. A. Ferrer Benimelli lo llena todo o casi todo, se hará bien en consultar los importantes trabajos que acerca de ella y de zonas colindantes publicaron en el biltimo decenio los también jesuitas Enrique Menéndez Ureña y Pedro Alvarez, sobre todo, el último Masonería y Librepensamiento en la España de la Restauración (Madrid, 1985); La Masoneria, escuela de formación del ciudadano. La educación interna de los masones españoles en el último tercio del siglo XIX (Madrid, 1996, 445 pp.). La obra de la catedrática madrileña $\mathrm{M}$. Dolores Gómez Molleda, La masonería en la crisis española del siglo XX (Madrid, 1986, $537 \mathrm{pp}$.), constituye, en realidad, la reconstrucción de la Orden en el primer trienio de la Segunda República exactamente hasta mayo de 1934, en que Martínez Barrios abandona la Gran Maestría. Basada casi exclusivamente en el archivo salmantino de la masonería y en una extensa bibliografía no siempre bien valorada, el análisis de los años veinte es tal vez desde el punto de vista metodologico la principal aportación de un libro estimable, enriquecido por un material gráfico valioso pero algo insuficiente, y afeado por erratas tipográficas de bulto (v. gr. p. 330).

Otra ruidosa vertiente del fenómeno religioso de la España moderna y contemporánea a la que nos aproximamos con renitencia, es -ya se habrá adivinado- la de la Inquisición. Produce ésta, como es bien sabido, una torrencial bibliografía que, curiosa y sintomáticamente, disminuye su curso al acercarnos a su desembocadura, esto es, a su extinción en el despegue de la edad contemporánea. Habiendo tenido el honor de colaborar en algunos de los estudios de conjunto más difundidos, no vamos a adentramos ahora en el escolio volandero de muchos de los meritorios trabajos consagrados a su final en la Regencia de $\mathrm{M}^{\mathrm{a}}$ Cristina. Como cifra y compendio de tales trabajos escogeremos la sobresaliente síntesis de uno de los más afamados especialistas, el catedrático oscense José Antonio Escudero: La abolición de la Inquisición española. Discurso leído el día 2 de diciembre de 1991 [R. Academia de Jurisprudencia y Legislación] en su recepción pública (Madrid, 1991, 115 pp.) Por su originalidad, se nos perdonará la quiebra de la promesa susomentada con la mención de una monografía reciente debida a A. de Prado Moura: Las hogueras de la intolerancia. La actividad represora del Tribunal inquisitorial de Valladolid (1700-l834) (Valladolid,l 196, 252 pp.), decantada lógicamente hacia su costa- 
do setecentista, resulta muy útil también al contemporaneísta, pese a algún que otro desenfoque y simplismo.

La fecha de la abrogación del famoso Tribunal así como las numerosas religaciones que ambos temas tienen con el antiguo régimen nos obligan a referenciar corticalmente el costado religioso y eclesiástico del carlismo. Algo sorprendentemente, no ha sido esta ladera de la comunión tradicionalista la más recorrida o frecuentada por sus últimos y, en general,jóvenes historiadores, cuyo número acrece incesablemente, por fortuna. A un cuarto de siglo de su exposición, el análisis de M. Revuelta se nos antoja el más sagaz y completo; al que complementan muy perspicazmente las páginas acerca de la misma materia de una de las tesis de doctorado más sólidas de la historiografía hispana de la segunda mitad del novecientos, debida a la pluma acribiosa de Alfonso Bullón de Mendoza: La primera guerra carlista (Madrid, 1992, 701 pp.).

Cataluña siempre ha tenido una fecunda presencia en el panorama historiográfico español. El eclesiástico dista, según es bien sabido, de ser una excepción. En su vertiente contemporánea, al lado de notables investigadores como Massot o Casimir Martí -(bien que su obra L'Església de Barcelona (1850. 1857). Implantació social $i$ dinamismes interns. (Barcelona, 1984, 2 vols.) signifique un descenso en una trayectoria historiográfica de envidiable entidad)-, descuella otro sacerdote. El monje monserratino Hilari Raguer i Suñer ha hundido su esteva en un decisivo segmento de la contemporaneidad más reciente. La segunda República y la guerra civil han tenido en su persona el investigador benedictino que necesitaban algunos de sus capítulos más controvertidos. En 1976 aparecía en la famosa Abadía La Unió Democràtica de Ca talunya i el seu temps (1931-1939), (582 pp.), en su versión original memoria presentada en la Sorbona bajo la dirección de Maurice Duverger y posteriormente defendida en la Universidad barcelonesa, siendo su ponente el catedrático granadino Manuel Jiménez de Parga. Cimentado en la roca viva de una documentación exhaustiva, si el calificativo es permitido en las disciplinas historiográficas, y en un aparato crítico de factura impecable, constituye una aportación sobresaliente no sólo al área de la que aquí nos ocupamos, sino también al de la estasiología. Al año siguiente se publicaba en la Ciudad Condal un libro promisorio de futuras y ambiciosas navegaciones del autor por las mismas aguas, ahora surcadas con rumbo divulgativo: La espada y la Cruz ( La Iglesia 1936-1939) (254 pp.)

Tiempo adelante, su libro acerca de uno de los colaboradores más estrechos del «cardenal de la Pau» será una envidiable muestra de una biografía elaborada con material abundante y novedoso, al tiempo que sostenida en una buida interpretación y expresada en un lenguaje de científica precisión y claridad: Salvador Rial, Vicari del Cardenal de la Pau (Barcelona, 1993, 330 pp.). Des- 
de esa fecha hasta la actualidad, su pluma, bien abastada siempre de información primaria y bibliografía copiosa, ha seguido acrecentando el acervo del contemporaneísmo español con obras, lato sensu, incluibles en su área eclesiástica, a la manera de su biografía sobre Manuel Carrasco i Formiguera: $D i$ vendres de Passió. Vida i mort de Manuel Carrasco y Formiguera (Monserrat, 1984,355 pp.). Entre sus artículos merecen reseñarse en particular «L'Esglesia i la Guerra Civil (1936-1939). Bibliografía reciente (1975-1985)», Revista Catalana de Teología, 11 (1986) pp. 119-252, muy útil y acribioso, «El Cardenal Gomá y la guerra de España», Arbor, 436 (1980), pp. 475-514, «Los Obispos españoles y la Guerra Civil», Ibid, 439-440 (1982), pp. 295-320.

Naturalmente, no vamos, ni por razones de espacio podemos, a engolfarnos en el detallado recuento de todas las aportaciones individuales de algún peso y valor. Las de los investigadores y catedráticos, entre otros, igualmente significativos y relevantes, como Fernando García de Cortázar -lástima grande que no haya aín publicado su tesis doctoral sobre un capítulo esencial de la Iglesia -seglares y curas...-ochocentista: los Congresos Católicos-; Jesús Martín Tejedor -insuperable conocedor de las corrientes que fertilizan la geografía espiritual del XIX (v.gr. «La presencia de Ventura Ráulica en el catolicismo liberal español», Hispania Sacra, 86 (1991), 503-529 pp. y con aportaciones descollantes sobre muchos de sus pasajes) y cuya obra Francisco Butiña y los Talleres de Nazaret. Utopismo socialista del siglo XIX en el catolicismo español. (Madrid, 1977, 575 pp.) es surtidor inagotable de ideas e hipótesis sugestivas-; Rafael Sanz de Diego -al que se debe una excelente biografía del primado Antolín Monescillo: Medio siglo de relaciones Iglesia-Estado: el Cardenal Antolín Monescillo y Viso (1811-1897) (Madrid, 1979, 498 pp.) y diversas y hondas catas en la dimensión social del catolicismo hispano: Pensamiento social cristiano. I. Las alternativas socialista, anarquista, comunista y católica ante el problema social español. (Madrid, $1989,5^{\mathrm{a}}$ ed., $550 \mathrm{pp}$.)-; Manuel Teruel y Gregorio de Tejada -tan buen conocedor de la Iglesia fernandina-; Cristóbal Robles indagador infatigable de las principales claves del catolicismo finisecular decimonónico, conforme lo prueban, entre otros, sus libros Insurrección o legalidad. Los católicos y la Restauración. (Madrid, 1988, 406 pp.) y José María de Urquijo e Ybarra. Opinión, Religión, Poder (Madrid, 1997, 692 pp.)-; Feliciano Montero -en posesión de una muy estimable obra acerca de la dimensión social de eclesísticos y seglares, y cuya tesis doctoral renovó planteamientos y enfoques: El primer catolicismo social y la Rerum Novarum (1889-1902) (Madrid, 1983, 495 pp.), así como autor de estudios del máximo interés, a la manera, entre otros muchos, de la panorámica acerca de El movimiento católico en España (Madrid, 1993, 96 pp.) o «Catolicismo, social en España. Una revisión historiográfica», Historia Social, 2 (1988), pp.157-64; Antón M. Pazos -en su currículo constan, aparte de las ya citadas

Hispania, del Mediterráneo al Atlántico

Hispania Sacra 51 (1999) 
colaboraciones con J. Andrés Gallego, dos libros notables: El clero navarro (1900-1936). Origen social, procedencia geográfica y formación sacerdotal (Pamplona, 1990, 503 pp.) y La Iglesia en la América del IV Centenario (Madrid, 1992, 429 pp.)-; Joan Bada -que hodierno ha trasplantado sus cuarteles al modernismo después de haber haber dado a las prensas una muy estimable obra L'església de Barcelona en la crisi de l'antic règim (1808-1833), primitiva tesis doctoral que tuvimos el honor de sugerir-; X. Ramon Barreiros Fernández -para el que la Iglesia gallega en su plasmación contemporánea no contiene secretos según ha patentizado en una destacada labor publicística-; el también veterano historiador Víctor Manuel Arbeloa -cuya intensa producción durante el decenio 1965-75 no ha tenido, por desgracia, continuidad, al menos en idéntico nivel, salvo su La semana trágica de la Iglesia en España (octubre de 1931) (Barcelona, 1976, 361 pp.)-; Juan María Laboa -en posesión de todos los conocimientos del rol político de la Iglesia de la transición y en días anteriores: Iglesia y Religión en las constituciones españolas (Madrid, 1981, 144 pp.)-; Emilio de la Parra antiguo alumno, al que tuvimos la fortuna de «reclutars para el en aquel entonces despoblado campo de investigación de la historiografía eclesiástica contemporánea y cuya tesis de doctorado se alinea en el segmento más cercano a nuestras preocupaciones: El primer liberalismo español y la Iglesia. Las Cortes de Cádiz (Alicante, 1985, 320 pp.); Luis Barbastro Gil: El clero valenciano en el trienio liberal (1820-1823). Esplendor y ocaso del estamento eclesiástico (Alicante, 1985, 278 pp.); Josefina Cuesta Bustillo -indagadora incansable de los caminos de la acción social de los cristianos españoles del novecientos, Sindicalismo católico agrario en España (19171919) (Madrid, 1978, 310 pp.), complementado con «Sindicación obrera católica en la crisis de 1917-1919. Problemática». Estudios sobre Historia de España, Obra Homenaje a Manuel Tuñón de Lara (Madrid, 1981, II, pp. 41-55), $\mathrm{y}$ a la que se debe un excelente panorama historiográfico de un segmento decisivo de la temática: «Estudios sobre el catolicismo social español (1915-1930). Un estado de la cuestión». Studia Historica Contemporanea, II, 4 (1984) pp. 193-245-; Juan José Castillo -(cuya tesis doctoral, El sindicalismo amarillo en España. Aportación al estudio del catolicismo social español (1912-1923) Madrid, 1977, 297 pp. está salpicada de hipotesis sugestivas, así como su artículo «Los socialistas ante el catolicismo social en España», Estudios sobre Historia de España. Homenaje a Manuel, Tuñon de Lara, Madrid, 1982, II, pp. 9-23, «parte de un capítulo introductorio de la tesis doctoral del autor» p.

8 «El presente trabajo forma parte del capítulo $V$ de nuestra tesis doctoral, de la que ya presentamos una síntesis en el VIII Coloquio de Pau, editado bajo el título La crisis del Estado español. 1898-1936, ver «Una perspectiva ante la crisis de 1917-1920. ¿Hubo respuesta católica?», pp. 379. $397 \%$, p. 41. 
9, e, igualmente, su obra, por el momento, más extensa Propietarios muy pobres. Sobre la subordinación política del pequeño campesino en España (La Confederación Nacional Católico-Agraria, 1917-1942), Madrid, 1979, 552 pp.)-; Leandro Higueruela del Pino, en quien la Sede Primada tiene a uno de sus más reputados especialistas: La Diócesis de Toledo durante la guerra de la Independencia española (Toledo, 1982, 291 pp.); D. Benavides Gómez, cuyo valioso libro Democracia y Cristianismo en la España de la Restauración (1875-1931) (Madrid, 1978, $391 \mathrm{pp}$.) viene a completar su tesis doctoral de la que dimos ya noticia: El fracaso social del Catolicismo español (Barcelona, 1973); Pere Anguera -de asombrosa erudición en todo lo concerniente a la historia contemporánea del Principado Catalán y entre cuya numerosa bibliografía referente de manera tangencial o directa a su dimensión eclesiástica, convendría tal vez subrayar Menjacapellans, conservadors $i$ revolucionaris (Reus, 1991, 189 pp.)-; Jesús Longares -cuya innovadora tesis doctoral fue dirigida por el autor de las presentes líneas: Política y Religion en Barcelona (1833-1843) (Madrid, 1976, $341 \mathrm{pp}$.), circunstancia que nos veda tributarle un bien merecido elogio-; José Sánchez Jiménez -El cardenal Herrera Oria. Pensamiento y acción social (Madrid, 1986, pp.) es un estudio muy acordado a la línea de investigación más proseguida por este profesor malagueño, cuyo envidiable dominio de la trabajosa andadura de nuestro catolicismo social ha vuelto a probarse recientemente: Caritas Española. 1942-1999. Acción social y compromiso cristiano. (Madrid, 1998, 381 pp )-; José Leonardo Ruíz -pieza mayor de su enjundiosa bibliografía: Política e Iglesia durante la Restauración. La Liga Católica de Sevilla (1901-1923) (Sevilla, 1995, 618 pp.)-; José Domínguez León, para el que la historia eclesiástica de la Sevilla del XIX no guarda secretos (la publicación de su tesis se demora en exceso); Miguel Angel Orcasitas -del que su Unión de los Agustinos españoles (1893). Conflicto Iglesia-Estado en la Restauración. (Valladolid, 1981, 315 pp.) aviva el deseo de ver pronto rematada su tesis doctoral sobre el P. Cámara-; Vito T. Gómez -a quien debemos una monumental biografía acerca de un purpurado muy destacado de comedios del ochocientos, El Cardenal Fr. Manuel García y Gil, O.P., Obispo de Badajoz y Arzobispo de Zaragoza (1802-1881) (Valencia, 1990, 994 pp.)-; Manuel Morán Ortí -tan diligente en sus análisis de la posición de la Iglesia docente cara al liberalismo gaditano-; Antonio Moliner Prada rastreador buido de tantas sendas de la Iglesia de la crisis del antiguo régimen-; Manuel Suárez Cortina -preocupado y atento por los fenómenos de la secularización y el anticlericalismo en la vida española finisecular-, Angel Martínez de Velasco -hacemos férvidos votos porque no esté muy lejano el día en que se decida a publicar el fruto de sus incontables rebuscas y escudriñamientos en innumerables archivos eclesiásticos en torno a la Iglesia fernandina-, etc,etc,

Hispania, del Mediterráneo al Atlantico Hispania Sacra 51 (1999) 
suprimen, por su cotización en el mundo intelectual, cualquier duda o temor ante el futuro de la disciplina que nos ocupa, de cuyo cultivo son fieles garantes.

El relevo también está asegurado según lo đescubren los estudios de José García Cuevas -el hecho de asumir la honrosa responsablidad de orientar su tesis doctoral sobre el cabildo cordobés a lo largo de casi toda la centuria decimonónica impide aquí calificarla con los adjetivos encomiásticos que en verdad exige, El cabildo catedralicio cordobés desde la revolución a la restauración (1778-1887) (Córdoba, 1996, 276 pp.)-; Angel Gonzalo Gonzalo sobre el mismo tema: El cabildo de la catedral de Burgos en el siglo XIX (l808-1902), Baena, 1993, 462 pp., tesis de doctorado bien pilotada por Jesús María Palomares; Basilisa López García -en su haber, una importante Aproximación a la historia de la Hoac. 1946-1981 (Madrid, 1995, 387 pp.); J. de la Cueva Merino-Clericales y anticlericales. El conflicto entre confesionalismo y secularización en Cantabria (1875-1923) (Santander, 1994, 417 pp.) es una tesis doctoral sobresaliente que augura un brillante trabajo en el campo de la historiografía eclesiástica-; José Luis Mínguez Goyanes -receptivo a dimensiones del apostolado católico hasta ahora investigadoramente inéditas ; ;Manuel Alvárez Tardio - uno de los varios jóvenes politólogos imantados por el trillado pero a la vez siempre atrayente tema de las relaciones entre la Iglesia y la Segunda República-; Samuel Garrido, cuya tesis doctoral reconstruye notablemente una actuación a menudo olvidada a escala nacional: Los trabajadores de las derechas. La acción social católica en los obispados de Tortosa y Segorbe (1877-1923). Castellón, 1983, 290 pp., etc., etc. Unos y otros, en compañía de los seniores arriba citados, harán con sus afanes que la historiografía eclesiástica española contemporánea deje de ser la cenicienta de la disciplina de Clío, catapultándola al escenario principal de las humanidades hispanas, afrontando sin angustias los desafíos que le depare un futuro tan dinámico como será el de los sucesivos presentes del siglo XXI.

Los parágrafos que deberían consagrarse al análisis pormenorizado de los trabajos y los días de los estudiosos acabados de mencionar, los destinaremos a la somera alusión de la aportación realizada por los no profesionales o especializados en otras áreas de la historia y de las ciencias sociales, menos comentados en las publicaciones y esferas especializadas, en tanto que aquéllos lo han sido y lo serán con asiduidad. Colocados, por las leyes de bronce de la edición, ante la difícil alternativa, nos decidimos a seguir, con lógica reluctancia, la opción señalada.

Un conocido ensayista, distinguido por su apertura cultural e imantado con fuerza por las vicisitudes políticas e ideológicas de la España contemporánea, el notario y jurídico militar, José María García Escudero, ha realizado frecuentes y prolongadas incursiones por el catolicismo de la misma época. Sus 
estudios, discretos en cuanto a la documentación, notables por su perspicacia y destacados por su talante liberal, se resienten, empero, de orfandad metodológica y capacidad de síntesis. Recluidos también en exceso en el plano de la política, son de mayor provecho para los interesados por esta última dimensión de la historia de las dos últimas centurias que para el análisis de la temática que centra las presentes páginas (No obstante el desapoderado afán de García Escudero por fundir ambos planos como trasunto fiel de la realidad de dicha etapa, la frontera entre ellas es más señalada de lo que él sostiene oportune $e t$ inportune, de forma muy particular en el tomo II de su obra Los cristianos, la Iglesia y la política (Madrid, 1992, 2 vols.), más en el primer tomo -Entre Dios y el César, 418 pp.- que en el segundo -España y América. Desde la Monarquía católica a la teología de la liberación, 351 pp-, que viene a ser su última visión de la trayectoria del catolicismo hispano desde la Edad Media a la época socialista. Igualmente, a través de la biografía de una personalidad a cuyo conocimiento había ya contribuido notablemente con aportaciones sustantivas, el por dos veces director de Cinematografía del régimen de Franco ha esbozado el itinerario o penúltimo segmento de la religión tradicional de los españoles: $D e$ periodista a cardenal. Vida de Angel Herrera (Madrid, 1998, 431 pp.).

Con más de una afinidad conceptual y de propósito respecto al autor susomentado, aparece la figura del destacado contemporaneísta Javier Tusell, admirable por su insomne laborar, su asombrosa capacidad de información y su acezante curiosidad intelectual. Varios son los estudios con los que ha ensanchado el caudal de esta corriente de la historiografía nacional. Dados los rasgos que conformaron el desenvolvimiento de la CEDA, los dos volúmenes que a su reconstrucción dedicara el catedrático barcelonés, pueden estimarse por más de un motivo como pertenecientes al ámbito. Sin embargo, al haber aparecido en 1974, los marginaremos de nuestra referencia para hacer más amplia la mención de otro de sus libros de temática en ancha medida religiosa: Franco y los católicos. La politica interior española entre 1945 y 1957 (Madrid, 1984), que viene a ser en buena parte la prolongación natural del libro anterior.

9 «No pretendí en mi libro [Conversaciones sobre Angel Herrera (Madrid, 1986, 518 pp.)] hacer un retrato acabado de Herrera, sino aportar todos los colores que habrá de emplear el que lo haga. A lo sumo, trazar el boceto a carboncillo, para que por encima se pinte el retrato definitivo. Y la utilización que se ha hecho de las Conversaciones por cuantos se han ocupado de Herrera me ha demostrado que hice una obra útil [...] El pensamiento de Angel Herrera fue el complemento de las Conversaciones. Pude incorporar mucho material inédito, procedente en su mayor parte de la correspondencia del cardenal [...] Se ha conservado en la misma habitación donde aquél pasó sus últimos affos y donde murí6. Todo sigue como él lo dejó. Hasta sus gafas en la mesilla de noche». Mis siete vidas. De las brigadas anarquistas a juez del 23-F. Barcelona, 1995, pp. 470 -71. Las tres últimas frases del texto precedente se reproducen ad integnum en la biografía que sobre el cardenal santanderino acabaría por publicar el ilustre acenepista- p.XXVI. Acerca de su etapa como director general, los capítulos X-XIII de sus recuerdos resultan muy sugerentes.

Hispania, del Mediterráneo al Atlántico Hispania Sacra 51 (1999) 
En las coordenadas en que se inserta es quizá la obra más valiosa de un' asunto abordado por Guy Hermet en su tesis doctoral, Los católicos en la España franquista (Madrid, 1986, 2 vols, 434 y 519 pp., respectivamente). Con el aporte de documentación inédita que enriquece casi todos sus libros de envergadura, esta monografía posee altas calidades de información y sagacidad y se ofrece más ponderada en la apreciación de la personalidad y obra de Franco que muchos otros de los estudios del propio Tusell acerca del dictador y su sistema. Otro de sus estudios alineados en el mismo tajo es el redactado en unión de su esposa, Genoveva García Queipo de Llano, El catolicismo mun dial y la guerra civil (Madrid, 1993). Singularmente, este implica el mérito de ser una de las pocas investigaciones de radio universal acometidas por la historiografía hispana, siempre tan corraleña incluso en sus plumas más sobresalientes, con la peraltada excepción del ya ha tiempo desaparecido catedrático hispalense Jesús Pabón. Aunque contiene muchas lagunas bibliográficas -en especial, en el tratamiento de lo francés- y es de redacción muy apresurada en algunos pasajes, como visión de conjunto merece una calificación superior. Con todo, las vías que abre son de más valor que sus catas específicas. Otra obra -en colaboración- del mismo autor al que consagramos este parágrafo, que puede incluirse lato sensu en nuestra materia -Manuel Giménez Fermández, precursor de la democracia española (Madrid-Sevilla, 1990)- supone a todas luces un pronunciado descenso en la jerarquía científica en que su producción se sitúa. La biografía del canonista hispalense es una incursión veloz y atrevida que, por su carencia documental e infirmidad contextual, no se ha visto recompensada por la fortuna.

Otro infatigable cultor del mismo campo historiográfico que el roturado por el catedrático catalán antecitado, Ricardo de la Cierva, ha transitado con asiduidad por el acotado en estas líneas. Reportajes periodísticos de vastos panoramas y cuestiones, las obras de este destacado especialista de la guerra civil y del franquismo dedicadas nuclear o corticalmente a la andadura de la Iglesia española e iberoamericana contemporáneas -registradas con agilidad y pulso narrativo- están dañadas de una morbosa subjetividad y descalificatoria unilateralidad: Jesuitas, Iglesia y marxismo (Barcelona, 1986); Obscura rebelión en la Iglesia. Jesuitas, teología de liberación, carmelitas, marianistas y socialistas: la denuncia definitiva (Barcelona, 1987). Libelista nato, el autor de Francisco Franco. Un siglo de España (Madrid, 1973, 2 vols.) no defraudará a los que acudan a sus trabajos en búsqueda de munición polémica y anticipados juicios finales; al tiempo que también colectarán, en esta selva selvaggia, datos curiosos, retratos vivos y visiones percutientes. Un amplio muestrario de ello encontrará el curioso lector en Las puertas del infiemo (Madrid, 1995) donde se trata de omni re scibile... et quibusdam aliis. Desde Lamennais y Gregorio XVI hasta Pablo VI y las tensiones en la Compañía de Jesús, episodios y per- 
sonajes relevantes de la historia de la Iglesia son llamados a capítulo por el autor que, en un nuevo camino de Damasco, rectificará, copémicanamente, las posiciones mantenidas hace un treintenio respecto a uno de los institutos religiosos españoles de ámbito más universal (pp. 567-89).

De producción más parsimoniosa y taraceada, el diplomático e ingeniero Javier Rubio García-Mina ha contribuído de forma sobresaliente al progreso de la historiografía eclesiástica de la Restauración, periodo que sus estudios han enriquecido en sus facetas exteriores. Su aportación subraya lo que con enfadosa insistencia hemos afirmado en esta y otras páginas: el avance de nuestra disciplina proviene en no pocas ocasiones de los afanes de investigadores interesados primordialmente por otros temas, que, en su prosecución, han recalado más o menos dilatadamente en las aguas del pasado religioso. Pocos ejemplos más expresivos de ello que éste que ahora nos ocupa. En su robusto y airoso fresco acerca de la política internacional española del último tercio del XIX, las relaciones entre Madrid y el Vaticano así como, es claro, sus repercusiones en la política interior del Sexenio y el canovismo, tienen las proporciones requeridas por su trascendencia. Llegarían quizás a las tres cifras el número de sus catas y análisis con que sus obras han dilatado la visión religiosa e incluso eclesiástica de los decenios finiseculares ochocentistas. Tal riqueza nos veda, bien se entiende, desgranarla. Quede únicamente aquí constancia de ello como exvoto y quizá como acicate para lectores todavía no beneficiados con el repaso de dichos estudios, entre los que destaca El reinado de Alfonso XII. Problemas iniciales y relaciones con la Santa Sede. Historia de la política exterior de España en la época contemporánea (II). (Madrid, 1998, 574 pp.). Nada falta -documentación primaria de archivos nacionales y foráneos, familiaridad hemerográfica, asimilación bibliográfica-y acaso nada sobra en sus páginas, ni siquiera tal vez el dolorido sentir por creerse voz clamante in deserto ante una historiografía oficial tan conformista y quizá tan cloroformizada como todo lo establecido.

Muchos más autores cubren con su trabajo el ancho campo de nuestro pasado eclesiástico. Todos, insistiremos una vez más, se han ganado esforzadamente el reconocimiento de la cultura española en las diversas parcelas que la integran. En la muy estimable de las síntesis divulgativas, las de la biografía destinada al gran público y de la monografía acometida para satisfacer legítimas preocupaciones o aficiones íntimas, desprendidas en un caso y otro de escrúpulos eruditos y miras acribiosas, son incontables los autores y títulos que comparecerían a la ligera revista llevada a cabo en las presentes páginas. Sacerdotes editorialmente prolíficos como el valenciano Francisco Martí Gelabert, el oscense José María Javierre o el navarro Francisco Rodríguez de Coro, laicos como Enrique Miret Magdalena, José María Jiménez Lozano -en su 
desigual producción merece destacarse Los cementerios civiles y la heterodoxia española (Mađrid, 1978, 273 pp.)-, Rafael Gómez Pérez o Francisco José Fernández de la Cigoña, comparecerían, entre otros muchos, pero en sus circunstancias muy destacadamente, a esa visita de dichos espacios de la bibliografía eclesiástica y religiosa. Figurando entre las más honrosas tareas del emborronador de estos apuntes su debida reseña en publicaciones especializadas singularmente, en la fundada en Barcelona por Jaume Vicens Vives en 1953, Indice Histórico Español-, remitiremos a lo allí escrito, atenazados como estamos por el dogal de las cortas dimensiones concedidas a estas páginas.

Igualmente otra nota personal nos invalida para juzgar, con la requerida imparcialidad y justeza, la aportación, que, en un estadio historiográficamente decisivo de nuestro país, supusieron para la adultez de la disciplina de la que ahora hablamos: las «Semanas Escurialenses de Historia de la Iglesia», celebradas durante el sexenio 1976-82. Foro plural y abierto, como todos los organizados por nosotros, y en el que ningún rincón del ayer más inmediato eclesiástico español quedó sin escudriñar, a él tuvieron la amabilidad de concurrir, a veces, con la preseas de su investigación, Antonio Domínguez Ortiz, Carlos Seco, Manuel Revuelta, Javier Tusell, Vicente Cacho Viu, Manuel Tuñón de Lara, Casimiro Martí, Mons. Rouco Valera, José Alvarez Junco, José Antonio Ferrer Benimelli, José Antonio Escudero, José Andrés Gallego, Juan Bta. Vilar, A. Fernández García, Celso Almuiña, Jesús María Palomares, etc., etc.

De los citados en último lugar -por mera razón cronológica en cuanto a su orden de actuación escurialense- no quisiéramos desaprovechar la oportunidad de realzar como es debido su aportación a la historiografía eclesiástica. Unidos por su docencia en la Universidad Pinciana y su dedicación al cultivo de la historia política con base documental preferentemente hemerográfica, los tres han enriquecido el conocimiento de varias parcelas de la España eclesiástica y religiosa de la etapa contemporánea. Junto con trabajos ya citados, Jesús $\mathbf{M}^{\circ}$ Palomares ha escrito páginas muy notables sobre la acción social de los catolicos castellanos así como acerca del culto josefino durante el XIX. De su lado, César Almuiña Fernández ha seguido en una línea de investigación ya iniciada en los comienzos de los setenta: la prensa de corte eclesiástico o, más exactamente, político-religiosa, toda ella en buena parte carlista durante el siglo XIX. A Antonio Fernández García se deben aportaciones de gran valía acerca de la Iglesia de la Segunda República y de la contienda fratricida, (entre las que resaltamos especialmente «La Iglesia española y la guerra civil», Studia Historica, III, 4 (1985), pp. 37-75-,)

Desearíamos reparar en el tramo final de este artículo en otro extremo relacionado con el parágrafo precedente. Por idénticas razones a las señaladas en el, no podemos glosar los importantes trabajos de estudiosos como Alfonso. 
Alvarez Bolado o José Ramón Montero, que, sin ser profesionalmente historiadores pero sí intelectuales rigurosos, han llevado a cabo incursiones muy fructíferas por nuestra temática -el libro del jesuita santanderino Para ganar la guerra, para ganar la paz. Iglesia y guerra civil: 1936-1939. (Madrid, 1995, 716 pp.) es de subido interés, e igual ocurre, no obstante su acusado apriorismo ideológico, con el del catedrático jerezano, La CEDA. El catolicismo social y político en la II República (Madrid, 1977, vol. I, 801 pp. y vol. II, 738 pp.), o los estudios de historiadores de otros terrenos colindantes que han enriquecido ocasionalmente la historiografía eclesiástica contemporánea, a la manera, sobre todo, de los segovianos Antonio Linage Conde -uno de los publicistas y eruditos de mayor rango y autoridad de las últimas décadas, de laborar incansable y fecundo- y Maximiliano Barrio Gozalo, autor de una importante tesis doctoral -Estudio socio-económico de la Iglesia de Segovia en el siglo XVIII (Segovia, 1982, 848 pp.)- y notable incursionador por diversos aspectos de la jerarquía de la crisis del antiguo régimen, conforme a las trazas de nuestro libro Sociología del episcopado español e hispanoamericano (1789-1985) (Madrid, 1986, 616 pp.) [Como su título indica elocuentemente, la muy meritoria obra del que fuera eximio canonista, Lamberto de Echeverría, no atiende a los aspectos contemplados en la obra precedente: Episcopologio español contemporáneo (1868-1985). (Datos biográficos y genealogía espiritual de los 585 Obispos nacidos o consagrados en España entre el I de enero de 1868 y el 31 de diciembre de 1985), Salamanca, 1986, 230 pp.l. Es igualmente muy estimable el Episcopologio español (1700-1867). Españoles obispos en España, América, Filipinas (Roma, 1992, 260 pp.) de V. Guitarte lzquierdo, quien dos años más tarde publicaría en la misma ciudad y editorial -Iglesia Nacional Española- la primera parte de dicho trabajo.

Finalmente, diremos que, debido al carácter generalmente extranjero de su edición original, no nos ocupamos aquí con la requerida latitud de los trabajos de hispanistas y estudiosos foráneos del catolicismo español contemporáneo. Como se sabe, entre éstos un puesto muy destacado ocupan el francés Gerard Dufour -destacado especialista en la crisis del antiguo régimen y magnífico estudioso del canónigo riojano J. Antonio Llorente: Juan Antonio Llorente en France (1813-1822). Contribution à l'étude du Liberalisme chrétien en France et en Espagne au début du XIX siècle (Ginebra, 1982, 375 pp.)-, los norteamericanos William J. Callahan -Iglesia, poder y sociedad en España, 1750-1874 (Madrid, 1989, 314 pp.) libro que se ofrece como una insuperable introducción al período analizado por su mesurada e informada pluma-, Stanley G. Payne publicista acucioso y fecundo, en cuya extensa producción figura una breve y notable síntesis: El catolicismo español (Barcelona, 1984, 315 pp.)-, la británica Frances. Lannon, los italianos Giuliana di Febo y Alfonso Botti -estos últimos más como promesas que como realidades cuajadas, según lo atestiguan 
sus breves libros La santa de la raza. Teresa de Avila: un culto barroco en la España franquista (1937-1962) (Barcelona, 1988, 136 pp.), de la primera, y el un tanto decepcionante del segundo El nacionalcatolicismo en España (18811975) (Madrid, 1992, $182 \mathrm{pp}$.), en el que el continente es más ambicioso que el contenido; como, a decir verdad, sucede igualmente con el de la citada Lannon: Privilegio persecución y profecía. La Iglesia católica en España. 1875-1975 (Madrid, 1990)-, en una, por fortuna, muy larga lista, acrecentada cada día, ya que en nuestra disciplina no se practica ni el monrósmo ni el chauvinismo y son bienvenidos todos los afanes.

De la tan estruendosa atmósfera de las publicaciones de las grandes editoriales comerciales, vengamos de nuevo a la recatada y silente de la investigación. Son muchos los asuntos que en ella esperan aún la atención de los estudiosos. No abocetaremos, claro está, un repertorio de las cuestiones que deberán afrontarse prioritariamente por la bistoriografía española eclesiástica contemporánea, pues este artículo es de balance y recapitulación y no de prospectiva y diseño. Unicamente nos atreveremos a indicar una posible estrategia investigadora que entraña también, a fortion, una elección epistemológica. Colocados en este terreno, un poco desiderativo sin duda, no vacilaríamos en mostrar una decidida inclinación por la pronta aparición de estudios sistemáticos y acribiosos de las distintas provincias eclesiásticas, según dejábamos ya indicado páginas arriba. Tales trabajos son los cimientos de cualquier análisis general y fundado de la religiosidad española o, al menos, de su porción mayoritaria y, en algunos periodos, abrumadoramente mayoritaria. Con limitaciones innegables, el marco diocesano es el más apropiado para las monografías de entidad y el que permite la mejor comparación y el más perfecto ensamblaje con los estudios de geograffa e historia secular. Dibujado con precisión este horizonte diocesano, preferentemente con investigaciones primarias o, en su defecto, con síntesis muy elaboradas, trabajos específicos pero de muy variado radio brotan casi instantáneamente. Así ha sucedido, por ejemplo, en Francia ${ }^{10}$. Este país, en vanguardia aún en nuestros estudios, ofrece el camino a seguir en tal direccion. Merced a una envidiable labor de conjunto acometida por figuras destacadas de dicha especialidad se ha rematado el vasto esfuerzo representado por la colección Histoires des diocèses de France (fundada por E. Jarri y J. R. Palanque, comprende una primera serie de cuatro volúmenes, que ha tenido continuación en otra de veintidos volúmenes, pilotada ésta por B. Plongeron y A. Vauchez).

En el tramo finisecular del segundo milenio todo lo concerniente al análisis intercultural, al estudio de los contactos y confrontaciones culturales y, en

10 M. LAGREE, «La monographie diocésaine et les acquis de l'historiographie religueuse française», Etudes d'histoire religieuse, 61 (1995), pp. 9-41. 
suma, a la visión del «otro», ha adquirido una relevante trascendencia. No es de esperar que a corto plazo cambie esta tendencia del mundo intelectual y sociopolítico, por lo que los títulos para su estudio en cualquier campo son patentes. También, por supuesto, en el nuestro. Su importancia en él incluso es mayor que en otros si se repara que, de modo indirecto, su ahondamiento repercutirá de inmediato en una apertura del paralaje en que permanecen enclaustradas las investigaciones concernientes a dicha área de la historiografía. También en él resulta obligado referirse al país vecino. Su historiografía religiosa vuelca hoy gran número de sus energías en lograr una ajustada reconstrucción de las relaciones entre los integrantes de diversas religiones en un mismo cuadro nacional y, en especial, entre los miembros de un mismo credo pertenecientes a enmarcamientos estatales distintos $y$, por ende, con una diferente identidad geografica y cultural.

Es gustoso observar que en el primer extremo se han verificado sensibles progresos en la historiografía española durante los tres últimos decenios. Tanto en la época medieval y moderna como en la contemporánea se ha avanzado ostensiblemente en la caracterización de la imagen del otro; bien que, a fuer de sinceros, habrá de declararse que en la última rama con más bajo perfil investigador. Sin embargo, toda la segunda vertiente está por completo sin roturar; y aunque no muchos, debido a la tibetanización y enclaustramiento del país en su recorrido contemporáneo, los contactos con el exterior poseen un indudable interés para la historia de dicho periodo. En amplia medida, la religión fue el principal ingrediente de la visión por nuestros inmediatos antepasados de otros pueblos y culturas. La ausencia de apertura al exterior, en fuerte contraste con la España ilustrada, se vio compensada en parte al convertirse nuestro país desde el romanticismo en meca de viajeros y turistas de toda suerte, cuya presencia daría lugar a estereotipos y retratos en los que, volveremos a repetirlo, el elemento religioso constituía el núcleo modelador. Por lo demás, la rica labor misionera, incluída la etapa mencionada, desplegada por monjas, monjes y frailes en América, Africa y Oceanía da a esta representación del otro un innegable valor histórico y antropológico. Igual cabe decir con nuestra ancha corriente emigratoria en dichos continentes. El vehículo de todo ello publicística, relato oral, pintura, etc., etc.- nos informaría del cuadro de valores desde el que se construye la imagen del otro, correligionario o no. Obvio es decir que el estudio interdisciplinar a escala nacional e internacional se impone aquí por sí mismo y por los frutos tan maduros que de él se recogerían.

En este galopante recorrido por los temas de indispensable y prioritaria investigación en la disciplina que nos ocupa, el de la espiritualidad no es, a buen seguro, el de menor importancia. Con esbozos y apuntes sugestivos a cargo de Baldomero Jiménez Luque es, en verdad, todo un mundo el que permanece 
fuera de la jurisdicción historiográfica. Si acaso no con la intensidad y riqueza de un Newman o un Lacordaire, de un Ozanan o de una Santa Teresita de Lisieux, no faltan en los últimos siglos del pasado de España autores laicos y eclesiásticos y corrientes e ideas que recuerdan la fuerza y originalidad de la literatura espiritual del Renacimiento y Barroco.

Tan culpable orfandad no provocará, sin embargo, demasiada irritación al reparar en otro vacío temático aún más penoso. En casi ninguna de sus expresiones, la religiosidad contemporánea hispana ha sido objeto de un estudio sistemático; incluso en la mayor parte de los terrenos faltan catas significativas y estimables. A finales del novecientos, aún no cabe señalar la fecha del inicio de una investigación rigurosa de dimensiones aceptables si no globales.

Sí constataremos, letíficamente, que un campo muy aledaño se ve visitado con frecuencia por historiadores, sociólogos y críticos literarios. El universo de la narrativa -grandes y modestos autores sin exclusión ni acaso tampoco, en útima instancia, prelación, ya que se busca en ellos la pintura de la realidad social-, $\tan$ ebullente y dionisíaco en nuestras letras contemporáneas, considerado como fuente para el estudio de los hábitos y comportamientos religiosos, ha tenido, por ejemplo, en Soledad Miranda -Religión y clero en la gran novela española del siglo XIX (Madrid, 1982, 281 pp.); Pluma y Altar en el XIX. De Galdós al cura Santa Cruz (Madrid, 1983, 350 pp.)- y en Francisco Pérez Gutiérrez -vid sobre todo su notable contribución al vol. I del T. XXXIX de la Historia de España de Ménéndez Pidal -Jover Zamora, La Edad de Plata de la cultura española (1898-1936). Letras, Ciencia, Arte, Sociedad y Cultura, titulada «La vida religiosa entre dos crisis: fin de siglo y guerra civil de 1936» (Madrid, 1994, pp. 509-654)- analistas sugerentes y rigurosos. El camino abierto o ensanchado por sus trabajos, junto con los de otros investigadores, se muestra, al tiempo que cada vez más transitado, como indispensable aproche a la gran cuestión focalizada, según decíamos, en el conocimiento de la religiosidad hispana de las dos últimas centurias; bien que los esfuerzos no han de unilateralizarse en su dimensión popular, a la moda de una antropología cultural muy horra, de ordinario, de coordenadas y referencias históricas. El estudio, verbi gratia, de los temas de la predicación dominical y cuaresmal y de la formación del ordo clericalis reportaría incuestionablemente réditos y ganancias muy positivas para el escrutamiento del fenómeno. Por desgracia, sin embargo, ello nos lleva a denunciar otro de los grandes vacíos de la historiografía de la que tratamos como es todo el universo de las órdenes y congregaciones religiosas, apenas científicamente rescatado en sus facetas más ininteresantes. Piénsese, por ejemplo, en la trascendencia de tal investigación para el análisis solvente y atópico de la enseñanza impartida en sus centros, como es de manera homeopática, intentamos en nuestro trabajo «La imagen literaria de los jesuitas de la postguerras (Apud Ignacio de Loyola, magister Artium en Parts, 
1528-1535. San Sebastián, 1991, pp. 223-233). Uno de los historiadores más sobresalientes de la actualidad, el ya citado M. Revuelta González, ha hecho recientemente una pequeña diversión de su camino real para volver a enriquecer la bibliografía eclesiástica: Los colegios de jesuitas y su tradición educativa (1868-1906) (Madrid, 1998, 595 pp.), pero su esteva ha roturado preferentemente alejados del aquí señalado. Consideración que cabe repetir con otros valiosos esfuerzos dentro del mismo campo de la enseñanza impartida por la Compañía, tales como el de F. de Lasala Claver -Orihuela, los jesuitas y el Colegio de Santo Domingo (Alicante, 1992), José María Calvo -Notas para una historia del Colegio de San Estanislao, (Málaga, 1982, p. 165)-, E. Rivera Vázquez Colegio Apóstol Santiago. Historia de una larga peregrinación (Vigo, 1993, p. 505)- y muy especialmente el coordinado por L. Fernández Martín sobre uno de los más acendrados centros de la pedagogía ignaciana: Historia del Colegio San José de Valladolid (Valladolid, 1981), enriquecido con una aportación del mismo M. Revuelta: «Los colegios de los Jesuitas durante la restauración alfonsinas; a los que hay que añadir el realizado de forma admirable por el catedrático extremeño Luis García Iglesias «Renovación en los colegios jesuíticos de la España Contemporánea», en sus artículos aparecidos en la revista $X X$ siglos. No nos movemos del mismo horizonte con la notable historia del empeño más querido de Manuel Domingo y Sol, fundador de los operarios diocesanos, escrita por J. de Andrés Hernán-Sanz: Pontificio Colegio Español de San José. Cien años de historia. (Roma, 1992), ni tampoco en el libro editado por dicha institutción y escrito por renombrados especialistas, Estudios y seminaristas y pastoral en un siglo de la historia de la Iglesia en Espa$\tilde{n} a$ (1892-1992). (Roma, 1992), entre cuyos trabajos sobresale el debido a V. Cárcel Orti, «El Colegio Español, la gregoriana y las vicisitudes pontificias españoles. Exitos y fracasos de los estudios eclesiásticos (1892-1939), pp. 203-77.

Por lo demás, un punto de partida acaso insustituible para acometer tan amplia y crucial tarea es el del mismo V. Cárcel Orti «Lenta restauración de las ordenes religiosas en la España del siglo XIX», Ephemerides Carmeliticae, II (1980), pp. 431-538, desde la 459, preciosos apéndices documentales. No insistiremos más por su título -Historia de la acción educadora de la Iglesia en España-, cabría tener la esperanza de que el tomo II de la obra dirigida por Bernabé Bartolomé Martínez (Madrid, 1997, p. 1025) se enfrentaría resueltamente con el asunto aquí tratado, pero ni siquiera en su capítulo II titulado "Actividad educadora institucional», en el que las páginas consagradas a la formación del clero secular y regular corren a cargo de Francisco Martín Hernández, hay trazas de ello.

No ahondaremos más el escalpelo o la mancera en la tierra virgen de buena porción del pretérito religioso más cercano. $\mathrm{Si}$, como ya ha tiempo pusimos de relieve en una amplia recensión crítica de la importante tesis doctoral del cate- 
drático segoviano Germán Rueda -La desamortización de Mendizábal en Valladolid. (1836-1853). Transformaciones y constantes en el mundo rural y urbano de Castilla la Vieja (Valladolid, 1980, 686 pp.)-, esta magna bisagra de la contemporaneidad española estaba a punto de conquistarse historiográficamente en toda su integridad -fácil vaticinio ya venturosamente materializado-, no ha ocurrido igual con el corolario de dicha sobresaliente tarea científica ${ }^{1 !}$. El paso siguiente al estudio desamortizador, la investigación de las bases económicas de la Iglesia posterior a aquél crucial acontecimiento, apenas si ha merecido algún análisis notable como, v. gr., el del sacerdote ignaciano Alfonso Verdoy acerca de la incautación de los bienes de la Compañía al comenzar la II República. (Los bienes de los jesuitas. Disolución e incautación de la Compañía de Jesús durante la Segunda República). Madrid, 1995, 372 pp.) El recuento -y con él, la denuncia podía, según hemos dicho, extenderse a otras muchas zonas del pasado material y social del hecho religioso en la España contemporánea. Otras plumas más capacitadas lo harán, acaso en fecha próxima.

Ojalá; y mejor aún, que a la constatación del hueco o la ausencia acompañe la monografía exhaustiva o la síntesis diligente.

$$
\text { **** }
$$

El balance que ahora acaba ha pretendido subrayar cómo la indigencia e intonsidad de la historiografía eclesiástica sobre la España contemporánea se ve afortunadamente acompañada de trabajos y autores muy estimables, pero aún en exiguo número $\mathrm{y}$, sobre todo, insuficientes hasta el presente para ofrecer una reconstrucción válida del pasado religioso de nuestro país en los últimos doscientos años.

Es probable que un enfoque distinto al que ha presidido estas líneas, como, v. gr., el temático, hubiera ofrecido una visión más completa de la historiografía eclesiástica del postrer cuarto de siglo; pero resulta asaz dudoso que el panorama así dibujado fuese más halagador que el descrito a través del método o la vía aquí seguidos. Por lo demás, ningún negativismo lo ha ennortado; pero tampoco ninguna fácil y engañosa complacencia. El rumbo de la historiografía eclesiástica hispana de las próximas décadas deberá trazarse desde el rigor a ultranza, no incompatible, desde luego, con un talante animoso y optimista.

Buen viento, en todo caso, para una empresa que, vitalizada y fecunda, será sumamente provechosa para la cultura española.

11 Páginas de literatura e historia contemporáneas. Madrid, 1985, pp. 76 y ss. 